\title{
Antusiasme Warga Blok Tempe Citeureup Bogor Menggunakan Bilik Pengukur Suhu Tubuh Pengantisikasi Covid-19
}

\author{
Bernadeta Siti Rahayu Purwanti $^{{ }^{*}}$, Nana Sutarna ${ }^{2}$, Nuralam $^{3}$, Latif Mawardi ${ }^{4}$, Syan Rosyid ${ }^{5}$ \\ 1, 2,3,4,5Program Studi Elektronika Industri, Jurusan Teknik Elektro, Politeknik Negeri Jakarta \\ *Penulis Korespondensi, B. S. Rahayu Studi Elektronika Industri, Jurusan Teknik Elektro, Politeknik Negeri Jakarta \\ Depok 16425. Email: rahayu.purwanti@elektro.pnj.ac.id
}

\begin{abstract}
ABSTRAK
Pandemi covid-19 yang merebak sejak awal tahun 2020 meresahkan masyarakat, perlu tindakan pencegahan. Demikian halnya Politeknik Negeri Jakarta, melalui kegiatan Pengabdian Masyarakat (PengMas) telah berkontribusi mencegah dan memutus rantai penyebaran covid-19. Sementara itu, kemampuan para ahli untuk menurunkan percepatan sebarannya di sejumlah negara belum signifikan. Terbukti aktifitas Pemerintah, pengusaha dan pekerja, organisasi-organisasi masih dibatasi waktu dan ruang geraknya. Seluruh lapisan masyarakat menghadapi tantangan besar dalam upaya perlawanan pandemi covid-19. Perlindungan keselamatan dan kesehatan di tempat kerja sedang krisis. Kekhawatiran kembali beraktifitas semakin ragu untuk dicapai, penekanan penyebarluasan belum signifikan keberhasilannya. Sorotan terhadap risiko Keselamatan Dan Kesehatan Kerja (K3) meningkat akibat penyebaran covid-19 makin meluas. Perkembangan eksplorasi perangkat untuk mencegah, mengendalikan risiko penyebaran covid-19. Antisipasi terhadap risiko psikososial, ergonomis dan risiko keselamatan/kesehatan warga agar minimal memproteksi diri terhadap covid-19. Selain tertib melaksnakan 3M (menggunakan masker, mencuci tangan, dan menjaga jarak), kelompok Dosen Prodi Elekronika Industri (EI) telah merealisasikan Bilik Pengukur Suhu Tubuh. Masyarakat sasarannya adalah warga Blok Tempe, Citereup, Kabupaten Bogor dengan melibatkan remajanya. Setelah Bilik Pengukur Suhu teruji fungsinya kelompok Dosen EI melaksankan pendampingan kepada kelompok Remaja Blok Tempe (RBT). Pelaksanaan pendampingan juga melibatkan beberapa mahasiswa agar remaja lebih nyaman mengikuti pendampingan cara penggunaan Bilik Pengukur Suhu Tubuh. Tahapan pelaksaan PengMas perancangan/instalasi bilik, serah terima, dan pendampingan sebagai rangkaian utuh mencapai tujuan pemberdayaan remaja Blok Tempe. Hasil pendampingan tim pengMas adalah kemandirian kelompok RBT menggunakan bilik untuk pengukuran suhu tubuh. Khususnya ketua RBT yang sangat antusias mengelola dan mencoba memindahkan Bilik ke area lain di sekitar Blok Tempe. Kegagalan uji alat melunturkan minatnya untuk dapat menggunakan bilik, mengulang instalasi dan berhasil.
\end{abstract}

Kata Kunci: Bilik Kelompok, Layanan, Pengukuran, Suhu.

\begin{abstract}
As a result of the activities of everyday community life on campus or as housewives, they often ignore heart health, which plays an important role in life. The covid-19 pandemic that has spread since the beginning of 2020 is troubling the public, it needs preventive action. Likewise, the Jakarta State Polytechnic, through its Community Service activities (CS) has contributed to preventing and cutting off the spread of covid-19. Meanwhile, the ability of experts to reduce the acceleration of its distribution in a number of countries is not yet significant. It is evident that the activities of the Government, employers and workers, organizations are still limited in time and space for movement. All levels of society face major challenges in efforts to fight the covid-19 pandemic. Safety and health protection at work is in crisis. Fears of returning to activities are increasingly hesitant to achieve, the emphasis on dissemination has not been significant. The spotlight on occupational safety and health (K3) risks is increasing as the spread of covid-19 is increasingly widespread. Development of exploration of devices to prevent and control the risk of spreading covid-19. Anticipate psychosocial, ergonomic risks and safety / health risks of residents in order to at least protect themselves against Covid-19. In addition to implementing 3M in an orderly manner (using masks, washing hands, and maintaining distance), the Industrial Electronics Study Program (IE) Lecturer group has realized a Body Temperature Measuring Room. The target community is residents of the Tempe Block, Citeureup, Bogor Regency, involving their teenagers. After the Temperature Measuring Room tested its function, the EI Lecturer group carried out assistance to the Tempe Block Youth group $(T B Y)$. The mentoring also involves several students so that teenagers are more comfortable following assistance on how to use the Body Temperature Measuring Chamber. The stages of implementing the CS
\end{abstract}


in designing / installing cubicles, handing over, and mentoring as an integral part of achieving the goal of empowering the Tempe Block youth. The result of the assistance from the Community.

Keywords: Community, Infrared, Measurement, Room, Services, Temperature

\section{PENDAHULUAN}

\section{Analisis Situasi}

Selama lebih dua dasawarsa seluruh wilayah di lima benua tertimpa musibah, muncul wabah penyakit menular. Penyebaran virus sangat pesat dan kekhawatiran masyarakat meningkat sejalan dengan meluasnya penularan covid-19. Negara-negara di dunia, termasuk Indonesia (Jawa Barat khususnya) sempat menjadi zona merah.

Penyebaran covid-19 di Indonesia diberitakan di media (Kompas.com, diakses pukul 12.37 WIB) kasus positif terbanyak adalah DKI Jakarta, menyusul Jawa Barat (Gambar 1). Update kasus virus corona di tingkat ASEAN, Indonesia terbanyak (5.923 kasus), dan berada di urutan 11 di Asia.

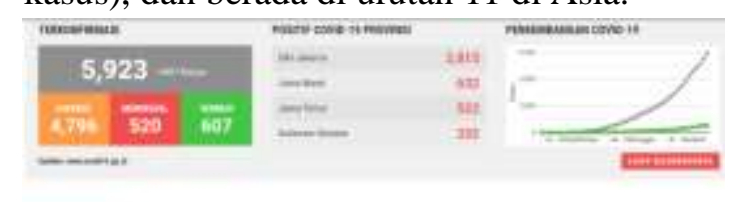

Update: Ada 5.923 Kasus Virus Corona, Indonesia Terbanyak di ASEAN, Nomor 11 di Asia

Gambar 1. Update Kasus Virus Corona Indonesia

Fenomena dan dilema muncul ketika datang ke Blok Tempe, Citeureup. Hal yang sangat riskan; warga aktif beproduksi 24 jam dengan jumlah pendududk (330 $\mathrm{KK}= \pm 800$ orang) hanya di RT 06/RW12, menempati area $2.800 \mathrm{~m}^{2}$. Praktis setiap KK hanya memiliki area $14 \mathrm{~m}^{2}$ untuk tinggal dan ruang produksi tempe/tahu. Ironisnya > $90 \%$ pencaharian warga adalah produsen/penjual tempe/tahu, hanya $6 \%$ berdagang/bekerja di tempat lainnya. Kepadatan penduduk dengan aktifitas produksi tersebut, sangat mustahil mematuhi lock down.

Himbauan social distance sulit direalisasikan, sehingga perlu solusi untuk anisipasi dini terhadap penyebaran covid-19.
Tamatlah wilayah Blok Tempe sebagai penyangga perekonomian di Desa Citeureup, jika satu orang saja menjadi suspek covid-19. Usaha warga di Blok Tempe Citeureup Kecamatan Citeureup, Kabupaten Bogor ini sangat pesat pertumbuhannya. Pada awal tahun 1993 hanya 12 perajin tempe, berkembang pesat dalam decade $<20$ tahun menjadi $>300$ perajin. Prioritas masalah yang utama adalah pencegahan dini dengan pemutus rantai penyebaran virus. Salah satu yang sudah umum adalah pemeriksaan suhu badan setiap 2 hari sekali. Suhu normal $<38^{\circ} \mathrm{C}$ ), acuan batas sesorang dinyatakan tidak demam dan salah satu tanda awal Covid-19. Bila warga disediakan sarana pemeriksaan suhu di Balai Desa minimal terindikasi gejalanya sejak dini.

Bahaya paparan radiasi infrared sudah cukup lama diteliti (Riadina. 1997), khususnya terkait efek biologis. Paparan gelombang elektromagnetis infrared masih banyak diperdebatkan. Walaupun demikian, terkait efek thermal masih perlu diteliti lebih lanjut. Akhurakhir ini topik paparan radiasi telah terpisah, menjadi efek radiasi elektromagnetik dan mekanis thermal.

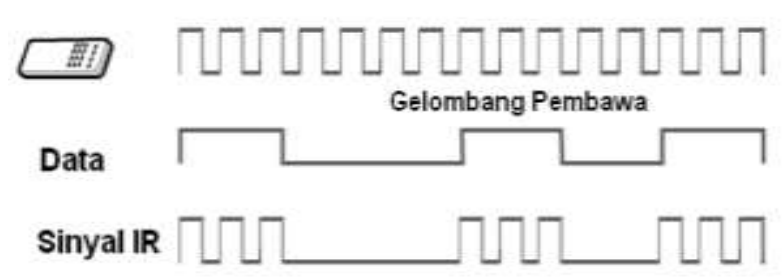

Gambar 2 Bentuk gelambang IR (Winardi dan

Kamisutara. 2016)

Selain jarak dan waktu, duty cycle PWM mempengaruhi termperatur hasil pengukuran. Hal tersebut akibat dari transmisi data dengan media perantara udara pada frekuensi 3040KHz (Winardi dan Kamisutara. 2016). Data ditransmisi memanfaatkan frekuensi pembawa berupa kode biner termodulasi, bentuk informasi yang diterima sensor IR (Gambar 2). 
Tabel 1 Spektrum Gelombang Elektromagnetik

\begin{tabular}{|l|l|}
\hline Spektrum & Frekuensi \\
\hline Sinar gamma & $1019-1025 \mathrm{~Hz}$ \\
\hline Sinar $x$ & $1016-1020 \mathrm{~Hz}$ \\
\hline Sinar ultraviolet & $1015-1018 \mathrm{~Hz}$ \\
\hline Sinar tampak & $\begin{array}{l}4 \times 1014-7,5 \mathrm{x} \\
1014\end{array}$ \\
\hline Sinar infra merah & $1011-1014 \mathrm{~Hz}$ \\
\hline $\begin{array}{l}\text { Gelombang } \\
\text { mikro }\end{array}$ & $108-1012 \mathrm{~Hz}$ \\
\hline Gelobang radio & $104-108 \mathrm{~Hz}$ \\
\hline
\end{tabular}

Sumber: Mahardika, $2009^{2}$

Klasifikasi frekuensi gelombang Tabel 1 (Mahardika. 2009), spektrum elektromagnetik. Spektrum gelombang elektromagnetik (Swamardika. 2009) mencakup rentang frekuensi yang lebar dan banyak sumbernya. Panjang gelombang radiasi inframerah (IR) 750 nm-100 $\mu \mathrm{m}$, dan $400 \mathrm{THz}-3 \mathrm{THz}$, atau rentang energi foton $12,4 \mathrm{meV}-1,7 \mathrm{eV}$. Sementara Standar ISO 20473 membagi infra merah sesuai panjang gelombang masing-masing; Near IR (NIR) 0.78-3 $3 \mu \mathrm{m}$, Mid IR (MIR) 3.0-50 $\mu \mathrm{m}$ dan Far IR (FIR) $50-1000 \mu \mathrm{m}$.

Perbedaan sisi tinjau, sensor infrared mempengaruhi jaringan syaraf; dari hasil riset (Nurcipto, Gandha. 2017) alat therapy Kesehatan, (Khayyat, LI. 2011) pengujian syaraf binatang, alat komunikasi (Victorya. 2015), (Agarwal et al. 2011). Merujuk pada alat terapi yang cara kerjanya disinarkan dan ditempelkan pada permukaan kulit dalam waktu tertentu. Hal ini serupa dengan TG, sehingga layak diteliti jarak aman dan waktu penyinaran.

Berkaitan dengan uraian beberapa peneliti terdahulu yang perlu diperhatikan terkait dengan bahaya radiasi pada penggunaan infrared, Kekhawatiran infrared pada thermometer gun perlu disikapi dengan bijak. Kenyataannya belum dijumapi korban akibat penggunaan thermometer gun. Maka menjadi pilihan untuk pemasangan sensor infrared nirsentuh. Pengabdian Masyarakat Berbasis Prodi terkait dengan penggunaan infrared sebagai instrument pengukur suhu tubuh nir sentuh. Cara penggunaannya sederhana dan mudah bagi pengukurnya dan nyaman bagi yang diukur suhu tubuhnya. Ujung thermometer gun diarahkan ke kening, suhu tubuh orang yang diukur tampil di LCD dispalai.

\section{Tujuan dan Manfaat Kegiatan}

Sesuai dengan rencana kegiatan, maka luaran yang dihasilkan atau ditargetkan dalam kegiatan PengMas D-3 EI, JTE, PNJ adalah :

a) menyediakan sarana pengukur suhu bagi warga Blok Tempe

b) menyukseskan program $3 \mathrm{M}$ dengan antisipasi penyebaran covid-19 dengan alat ukur suhu nirsentuh

c) melatih ketua, dan beberpaa pengurus kelompok RBT sebagai penggerak, pengelola bersih dan sehat lingkungan desa citeureup

d) merealisasikan program UP2M PNJ untuk berpartisipasi ke masyarakat mencegahan dan memutus rantai penyebaran covid-19.

\section{METODE PELAKSANAAN}

\section{Sasaran kegiatan}

Yang menjadi sasaran pelaksanaan kegiatan pendampingan adalah para remaja Blok Tempe. Mereka tergabung dalam berbagai aktifitas yang terkait dengan pengelolaan kebersihan dan Kesehatan. Sesuai dengan program P3M PNJ tahun 2020 khusus berkontribusi terhadap antisipasi penyebaran cpvid19. Oleh karena itu perlu ditunjuk beberapa remaja yang bersedia belajar/mengoperasikan cara kerja, pengugunaan bilik pengukur suhu tubuh. Penggunaan bilik harus memandirikan kemampuan remaja untuk menjaga lingkungan agar bersih, sehat, indah, khususnya layanan kesehatan mandiri dari warga untuk warga.

\section{Lokasi kegiatan}

Wilayah Rukun Tetangga Blok Tempe, Desa Citeureup, Kabupaten Bogor sebagai area aktifitas Kelompok RBT. Area sebagai tempat tinggal dan usaha orang tua para remaja, juga sebagai sarana bersosialisasi dan berorganisasi para karang taruna. Posisi tepatnya adalah RT 06, RW XI (Gambar) dengan jumlah $\pm 330 \mathrm{KK}$ 
sebgai pembuat/pedagang tempe/tahu atau kebutuhan pokok masyarakat Bogor.

\section{Metode yang digunakan :}

Beberapa metode yang digunakan adalah :

a) metode pendampingan untuk:

(1) penggunaan tombol-tombol pada bilik pengukur suh kepada kelompok RBT

(2) perawatan sistem elektrik dan mekanik bilik pengukur suhu

b) metode penyebaran informasi teknologi pengukur suhu di dalam bilik dan

c) metode pengenalan wawasan penggunaan pengukur suhu tubuh di dalam bilik

d) metode sosialisasi terhadap masyarakat luas kegiatan PengMas berbasis Prodi yang bermanfaat bagi masyarakat.

\section{HASIL DAN PEMBAHASAN}

Ruang bilik pengukur suhu juga dilengkapi sinar UV sistem pembersih HP, kacamata, topi dan lain-lain selama muat masuk ke dalam box. Bilik pengukur suhu juga dilengkapi dengan sistem peringatan untuk memejamkan mata setiap sesorang sudah menekan pedal pengaktif sinar UV. Pengaktif pengukur suhu bersebelahan dengan pedal pengaktif UV. Dinding bilik tepat di atas masing-masing pedal tulisan suhu dan UV, agar pengguna tidak keliru injak.I

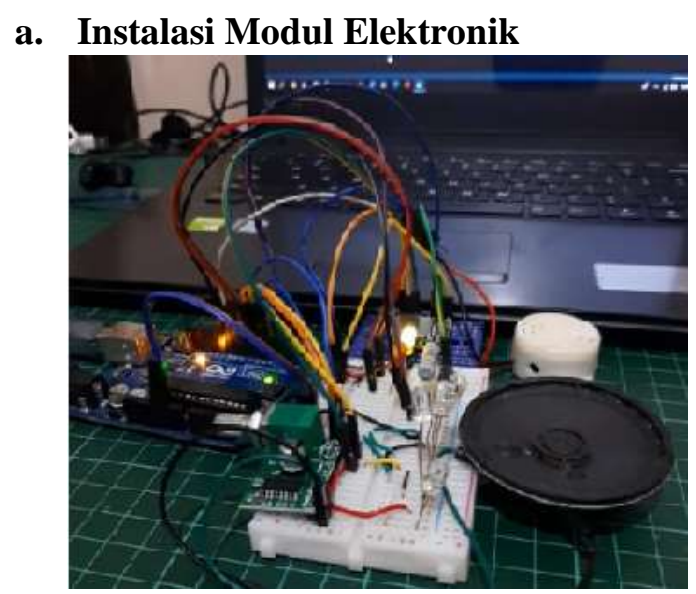

Gambar 3 Instalasi Box Pendeteksi Suhu dan Sinar UV (4-5 08 20)
Sebelum diinstalasi dan dipasang ke dalam box yang di dalamnya terdapat modul sensor inframerah, mikrokontroler, Uji fungsi modulmodul elektronik (Gambar 3) sebagai alat pendeteksi salam box 1, dan penyinaran sinar UV box 2 .

b. Keterlibatan Mahasiswa D-3 EI

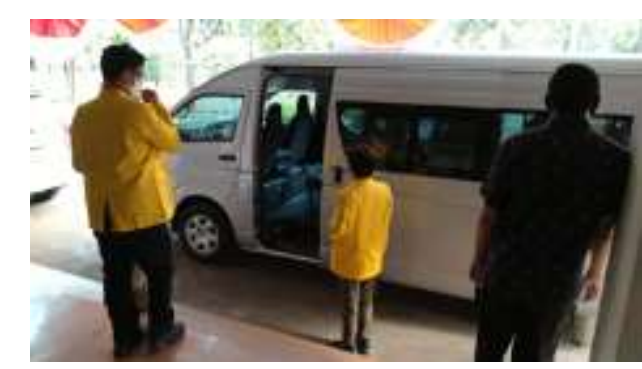

Gambar 4 Partisipasi Mahasiswa Menuju ke Blok Tempe Desa CIteureup

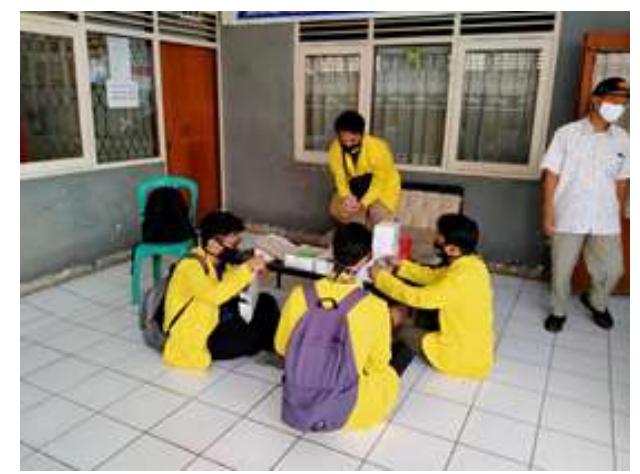

Gambar 5 Mahasiswa Menyiapkan Acara Serah Terima di depan Kantor Desa

Sejak mulai dari perancangan, instalasi, pemasangan bilik hingga persiapan acara serah terima melibatkan mahasiswa EI; yaitu keberangkatan dari depan gedung J, PNJ (Gambar 4) dan kegiatan di Kantor Desa Citeureup (Gambar 5).

\section{c. Pelaksanaan 3M-Pembagian Masker}

Masker berlogo Pengabdian Masyarakat Prodi D-3 EI. Sesuai protocol covid-19, setiap aktifitas wajib mengenakan masker wajah (Gambar 6). Hal ini juga dilaksanakan, dengan membagi 15 lusin masker untuk warga yang mengukur suhunnya setelah acara serah terima bilik (Kamis, 3 September 2020). kegiatan Pengabdian Masyarakat Prodi D-3 EI. 


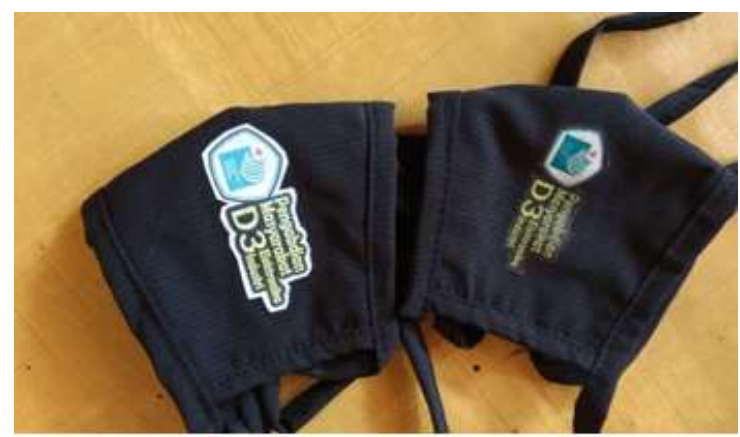

Gambar 6. Masker Pengabdian Masayarakat D-3 EI Berlogo PNJ

d. Seremonial Pengabdian Masyarakat Prodi D-3 EI

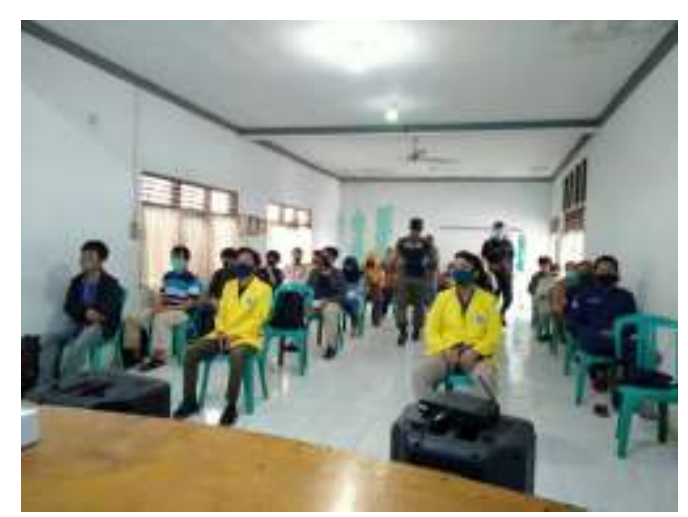

Gambar 7. Mahasiswa Warga Blok Tempe pada Acara Serah Terima Alat di Kantor Desa

Serah terima Bilik Pengukur antara ketua PengMas dan Ketua RBT (Kamis, 3 September 2020). Pembukaan acara penyerahan di ruang Balai Desa Citeureup, dibuka oleh Pak Padi, didampingi seluruh aparat/jajarannya. Penggunaan masker berlogo. Sambutan dari Kepala Desa dan Ketua RBT memberi sambutan. Protokol covid-19 tetap dilakukan oleh para aparat desa dengan penataan kursi berjarak satu meter kiri/kanan/muka/belakang.

Hal tersebut menunjukkan bahwa aparat desa tertib menjalankan social distancing. Walaupun sedikit agak berbeda bila berpapasan dengan warga penghuni Blok Tempe. Mereka memiliki cara tersendiri untuk menjaga staminanya, minum jamu jawa dari rebusan campuran kunyit, jahe, dan sereh. Disinfectant dengan air asam untuk cuci/membersihkan tangan. Warga juga senang dan langsung memakai masker (Gambar 7) yang dibagikan saat demo pengukuran suhu di dalam bilik. Antusias untuk menggunakan bilik pengukur suhu terlihat sejak awal yaitu lima hari menjelang serah terima.

c. Penandatanganan Berita Acara Serah Terima Alat

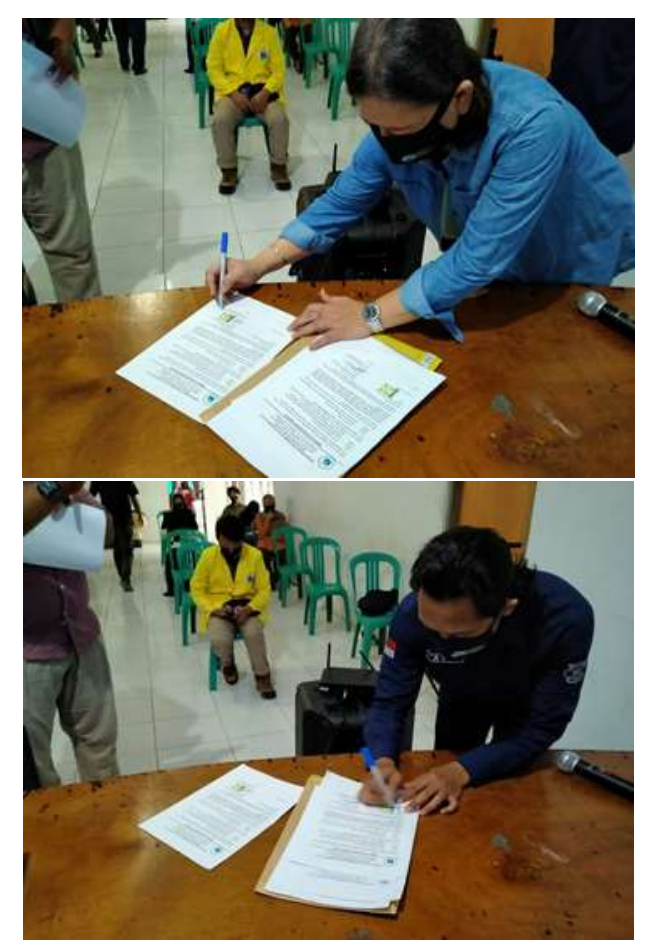

Gambar 8 Penandatangan Berita Acara Serah Terima Bilik Pengukur Suhu

Berita acara serah terima Bilik Pengukur Suhu ditandatangani (Gambar 8) oleh Ketua Panitia (Ibu Purwanti) dan Ketua Kelompok Remaja Blok Tempe (Mas Al) sebagai pengelola alat. Suistanabel fungsi dan penggunaan bilik bila covid-19 tidak atau berlalu di akhir 2020 juga telah disepakati kedua belah pihak. Bilik diredesain menjadi ruang penimbang dan pengukur tinggi badan dalam kegiatan Posyandu/Posbindu. Pengembangan fungsi bilik dengan penambahan perangkat elektronika agar sistem terintegrasi ke PC di Balaidesa atau Pos Kesehatan. Terealisasinya sistem integrasi ini menuju ke Blok Tempe sebagai pengguna teknologi PNJ dan sumber informasi kesehtan warga dengan antisipasi dini terhadap covid-19. 
d. Sampel Pengukuran Suhu Tubuh di dalam Bilik

Hasil pengukuran suhu dengan sampel warga, aparat desa, dan mahasiswa PNJ. Suhu udara di area Blok Tempe cukup tinggi $\left(32{ }^{\circ} \mathrm{C}\right)$ dibaca dari HP sesuai display dari BMKG. Hal tersebut berpengaruh juga suhu tubuh semua orang yang mengukur suhu di bilik (semuanya $\geq 36^{\circ} \mathrm{C}$ ), walaupun masih tergolong normal $\left(<37^{\circ} \mathrm{C}\right)$.

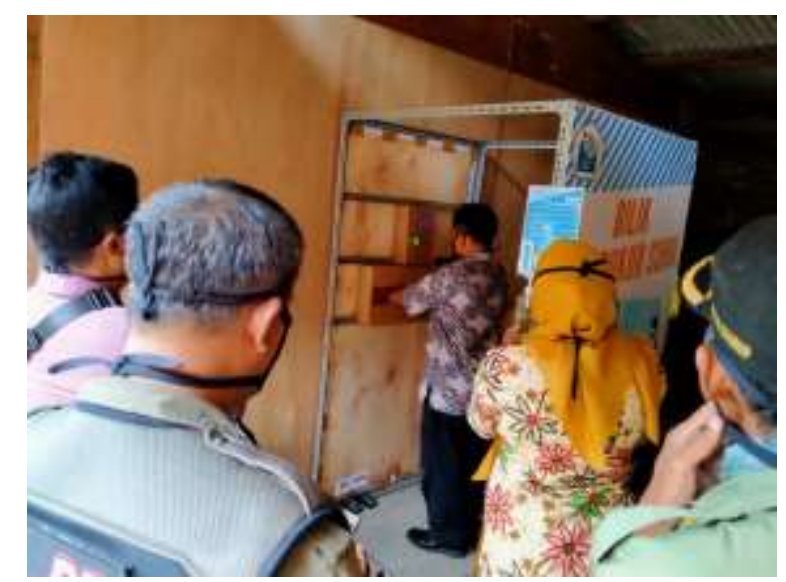

Gambar 9 Kepala Desa Berpartisipasi Mengukur Suhu Tubuh dan Membersihkan HP

Pak Padi, sebagai kepala Desa Citeureup juga sangat kooperatif dan antusias menerima kehadiran rombongan PengMas Prodi D-3 EI, JTE, PNJ. Para Dosen Prodi D-3 EI berdiskusi terkait kelancaran pelaksanan PengMas Berbasi Program Studi. Pak Padi memasukkan HP nya di dalam box UV setelah mengukur suhu tubuhnya di dalam bilik (Gambar 9).

\section{KESIMPULAN DAN SARAN}

Seluruh perangkat alat ukur suhu di dalam bilik telah berhasil direalisasikan sesuai tujuannya, untuk memonitor kenaikan suhu tubuh warga Blok Tempe, Citeureup, Bogor. Pendampingan Remaja Blok Tempe untuk mengoperasikan telah selesai, ketua kelompok RBT sudah mengerti cara penggunaan dan pengukuran suhu tubuh di dalam bilik.

\section{UCAPAN TERIMAKASIH}

Terimakasih diucapkan kepada Pusat Penelitian dan Pengabdian Masyarakat (P3M) yang telah memberikan dana sehingga PengMas D-3 Elektronika Industri dapat terselesaikan.

\section{DAFTAR PUSTAKA}

Agarwal, Hamada AJ, dan Singh A. 2011. A. Cell Phones and Their Impact on Male Fertility: Fact or Fiction. The Open Reproductive Science Journal. 5: 125-37.

Khayyat, L. I. 2011. The Histopathological Effects of An Electromagnetic Field on The Kidney and Testis of Mice. EurAsian Journal of BioSciences. 2011; 5: 103-109.

Mahardika I. P. 2014. Efek Radiasi Elektromagnetik Ponsel terhadap Kesehatan Manusia. [document on the internet] [cited 2014 November 21] http://mahardikaholic.files. wordpress. com/2009/12/efek-radiasi-gelombang.

Nurcipto, D. Gandha, G. I. 2017. Pengendalian Dosis Inframerah pada Alat Terapi Menggunakan Pulse Width Modulation (PWM). Setrum. 6(2), 194-204. Desember 2017 p-ISSN: 2301-4652/e-ISSN: 2503068.

Riyadina, W 1997. Efek Biologis dari Paparan Radiasi Elektromagnetik Vol VII No 01. Hal. 9-11. Pusat Penelitian Penyakit Tidak Menular. Media Litbangkes, Badan Penelitian dan Pengembangan Kesehatan Depkes.

Swamardika. I. B. A. 2009. Pengaruh Radiasi Gelombang Elektromagnetik Terhadap Kesehatan Manusia (Suatu Kajian Pustaka). Elektro. 8 (1) Januari-Juni 2009 hal 106-109.

Victorya, R. M. 2015. Effects of Handphone's Electromagnetic Wave Exposure on Seminiferous Tubules. J. MAJORITY. 4 (3), Januari 2015 hal. 96-100

Wahyu, Y. 2013. Efektifitas Jarak Infra Merah terhadap Ambang Nyeri”, Portal Publikasi Ilmiah Universitas Muhammadiyah Surakarta. 
Winardi, S. Kamisutara, M. 2016. Pengendali Tanpa Kabel Lampu Dimmer LED Menggunakan Microcontroller dengan Metode PWM (Pulse Width Modulation)
Prosiding Seminar Nasional Sains dan Teknologi ke-7 Universitas Wahid Hasym Semarang. 